Hemsley-Brown J.V. and Oplatka, I. (2005). Bridging the Research-Practice Gap: barriers and facilitators to research use among school Principals from England and Israel, International Journal of Public Sector Management, 18, 5, pp 424-446.

\title{
Bridging the gap: barriers and facilitators to research use among school principals from England and Israel
}

Dr Jane Hemsley-Brown

School of Management, University of Surrey, Guildford, GU2 7XH, Surrey, UK

Email: j.hemsley-brown@ surrey.ac.uk

Tel: +44 (0) 1483682045

Dr Izhar Oplatka

Department of Education

Ben Gurion University

P.O.B 653

Beer Sheva

Israel, 84105

Keywords:

Dissemination

Research utilisation / utilization

Use of research

Research use

Public sector research 
Hemsley-Brown J.V. and Oplatka, I. (2005). Bridging the Research-Practice Gap: barriers and facilitators to research use among school Principals from England and Israel, International Journal of Public Sector Management, 18, 5, pp 424-446.

\section{Bridging the gap: barriers and facilitators to research use among school principals from England and Israel}

\section{Abstract}

When a professional practitioner is faced with making a decision about what to do in a particular situation, do they base that decision on findings from research? This paper reports on qualitative and quantitative research which examined school principals' perceptions of barriers to the use of research. To facilitate a comparison the study was conducted simultaneously in two countries: England and Israel using interviews, focus groups and the Barriers Scale survey instrument (Funk et al., 1991).

The results of tests indicated that factors associated with the research itself, (e.g. relevance and access), were significant barriers to research use for principals from both countries (compared with factors associated with: the setting; the presentation of research; and the individual).

The paper concludes that multiple strategies would be required to address a number of issues related to the dissemination of research and ways of addressing the gap between the aims of researchers, and the needs and expectations of practitioners.

156 words 
Hemsley-Brown J.V. and Oplatka, I. (2005). Bridging the Research-Practice Gap: barriers and facilitators to research use among school Principals from England and Israel, International Journal of Public Sector Management, 18, 5, pp 424-446.

\section{Bridging the gap: barriers and facilitators to research use among school principals from England and Israel}

\section{Introduction}

In recent years there has been considerable interest and debate about the 'gap' between research and practice, and a number of strategies have been put forward to enhance research utilisation - i.e. to facilitate greater use of the evidence from research (Louis, et al, 1985; Louis, 1992; Klein, 1993a, 1993b; Huberman, 1993; Louis, 1996; Hammersley, 2000; Schmitt, M. 1999; NCDDR, 2000). A number of empirical studies have concluded that there is a tension between the users of research (managers and practitioners) and researchers, based on the differences in their professional goals. Practitioners are identified as seeking new solutions to operational matters whilst the researchers are characterised as seeking new knowledge (HemsleyBrown and Sharp (2003).

When a professional practitioner in education is faced with making a decision about what to do in a particular situation, on what do they base that decision? Dobby (1999) argued that practitioners ought to base their practice on the least biased and most reliable evidence of what is likely to work. However, he claimed that few educators relied on educational research results because they believed that research was removed from the realities of the classroom and relied almost exclusively on statistical significance (Bracey, 1989). More recently, Louis (1996) reviewed the emerging theories on knowledge utilisation in the context of educational improvement and concluded that the dominant paradigms were not adequate to explain what was actually happening in relation to dissemination and utilisation of knowledge. 
Hemsley-Brown J.V. and Oplatka, I. (2005). Bridging the Research-Practice Gap: barriers and facilitators to research use among school Principals from England and Israel, International Journal of Public Sector Management, 18, 5, pp 424-446.

Studies that have made specific comparisons between teachers and other professionals have tended to conclude that educationalists were less likely to use research literature than other professionals (Latham, 1993; Hannan, et al., 2000) - although there appear to be some common barriers to the use of research in both medicine and in education (Hemsley-Brown and Sharp 2002). Hargreaves (1996) further prompted debate about research use following his keynote address at the Teacher Training Agency Annual conference, by claiming that teaching is not a research-based profession. Hargreaves compared teaching to the medical profession, where he claimed professional decisions, judgements, diagnoses, treatments and so on were based on the best available evidence (Hemsley-Brown and Sharp 2002). A study which compares the two professions would seem to be appropriate therefore, and this study aimed to enable that comparison by using a research instrument which has been developed and widely used in the healthcare profession (Funk et al, 1991) to examine school principals' perceptions of barriers to the use of research in two countries: England and Israel. This is a study therefore, has implications for other organisations within the public sector, since the results of this study of the education sector can be compared with the results of studies conducted in the healthcare sector.

The paper begins by defining the terms, followed by a critical review of the literature on research utilisation in the education and healthcare, and summary of the cultural dimensions of the research.

\section{Defining the terms}

Prior to embarking on this research it was important to define the specific meaning of "research", and the meaning of "use" in the context of the study. Research has been 
Hemsley-Brown J.V. and Oplatka, I. (2005). Bridging the Research-Practice Gap: barriers and facilitators to research use among school Principals from England and Israel, International Journal of Public Sector Management, 18, 5, pp 424-446.

defined as 'an original investigation undertaken in order to gain knowledge and understanding" (HEFCE, 1999 p261), or as 'systematic enquiry made public' (Stenhouse, 1987 p74) and these definitions provided the basis for our understanding of these terms. Walter et al., (2003 p.11) further explain that 'diverse models have attempted to explicate "research use" and a key distinction can be made between "conceptual" use, which brings about changes in levels of understanding, knowledge and attitude, and "instrumental", or direct, use, which results in changes in practice and policy making (Huberman, 1993)'.

In the context of this study 'research' was defined as: empirical work carried out by others and reported in the public domain e.g. published research findings and theories that emerge from research findings; and empirical work carried out by managers and practitioners for their own use - but also disseminated to others (as opposed to work carried out entirely for their own use). The term 'use' was generally taken to mean instrumental use, or putting into practice an intervention, a theory or an idea that emerged as a result of the research process - where the findings from that research has been reported or disseminated to others (Wilson et al., 2003) .

The study on which this paper is based, posed two major questions: first, which are the most critical barriers to research utilization among school principals? Furthermore, studying and understanding phenomena in the context of foreign systems can often provide greater insights into our own ways of working (Dimmock and Walker, 1998). 'The identification of similarities and differences between systems is important in that it can help clarify problems of reform and change by generating informed cross-cultural fertilization of ideas and experiences'. (Dimmock and Walker, 
Hemsley-Brown J.V. and Oplatka, I. (2005). Bridging the Research-Practice Gap: barriers and facilitators to research use among school Principals from England and Israel, International Journal of Public Sector Management, 18, 5, pp 424-446.

1998 p561). On this basis, the second question was: to what extent do the barriers to research use in England, differ from other countries? Finally, a key question which needs to be addressed is - which factors do facilitate the use of research, from the perspectives and experiences of potential users?

This paper reports on a comparative, multiple methods study: a quantitative survey, using the Barriers Scale (Funk et al., 1991), and qualitative research which examined the barriers and facilitators - or obstacles and incentives - to research utilisation among school principals from two countries: England and Israel.

\section{Research use in the public sector}

Exploring ways of bridging the gap between research and practice is not new, the subject of facilitators and barriers to the use of research in particular, has been the focus of much speculation and discussion in education (Fleming, 1988; Rauch, 1991; Bassey, 1992; Turnbull, 1992; Malouf and Schiller, 1995; Maccoll and White, 1996; Staller, and; Kirk, 1998; Deforges, 2000; Tierney, 2000). However, since Hargreaves (1996) address, there has been considerable renewed interest in the topic and the communication difficulties and differing agendas that hamper the link between social science researchers and educators (Hallinan, 1996) has been debated at length. Hillage et al. (1998) found that actions by decision-makers in education were insufficiently informed by research, and dissemination was viewed as problematic. They identified a number of specific concerns: limited use of journals and the inaccessibility of journals; lack of encouragement given to dissemination to users; absence of time and support to help potential users to access research. 
Hemsley-Brown J.V. and Oplatka, I. (2005). Bridging the Research-Practice Gap: barriers and facilitators to research use among school Principals from England and Israel, International Journal of Public Sector Management, 18, 5, pp 424-446.

Research evidence indicated that the volume, applicability and ambiguity of research material have been key barriers to research use by those in education (Castle, 1988; Cousins and Leithwood, 1993; Shkedi, 1998). In 1988, Castle provided list of suggested factors which could facilitate increased use of research findings by teachers which included: making information readily available; enabling teachers to devote time to reading research; use of outside consultants; providing evidence of the benefits of using research; ensuring that research had practical application; and promotion of a colleagial atmosphere between researchers and teachers. However, at the end of the 1990s it was clear that despite such recommendations, little had been done to address the issues.

In a study conducted in Israel (Shkedi, 1998) teachers also argued that they did not use research literature because they perceived it to be irrelevant, unhelpful and too theoretical. A comparative study by Saha et al., (1995) and Biddle and Saha, (2000) also examined attitudes towards educational research held by school principals (head teachers) from two countries, and aimed to identify a number of factors that helped to explain differences in attitudes. This research, conducted in the State of Missouri USA, Australia Capital Territory and South Australia, found the following barriers to research use which, related to the research itself: 30 per cent of principals said that research was irrelevant to their needs and 18 per cent said that they had no time to read research findings. The issue of dissemination of research findings was also mentioned by 16 per cent of principals who indicated that research knowledge was poorly communicated. 
Hemsley-Brown J.V. and Oplatka, I. (2005). Bridging the Research-Practice Gap: barriers and facilitators to research use among school Principals from England and Israel, International Journal of Public Sector Management, 18, 5, pp 424-446.

A review of the literature on research utilisation (Hemsley-Brown, 2004) supports these findings, and concluded that key barriers to research use were the accessibility and relevance of research, trust and credibility; the gap between researchers and users, and organisational factors. Further support is provided by Wilson et al., (2003) in an empirical study conducted in the UK. They claimed that one of the key barriers to research use among principals was lack of time and problems accessing research, due to constant pressure to change within the teaching profession. The authors suggested that 'teachers can view the introduction of new projects and ideas as burdensome' (p.12).

In view of the focus on evidence-based practice, there has also been much discussion of research utilisation in the healthcare sector (e.g Macguire, 1990; Winter, 1990; Bassett, 1992; Closs and Cheater, 1994; Rodgers, 1994; Moore, 1995; Lacey, 1996; Schmitt, 1999; Bryant 2000; Rodgers, 2000). Following the development of the 'Barriers Scale' (Funk et al., 1991) there have been a number of replica studies in the field of nursing (Champion and Leach, 1989; Bostrum and Suter, 1993; Lacey, 1994; Rodgers, 1994; Barta, 1995; Funk et al., 1995; Hunt, 1996; Meah et al., 1996; Camiah, 1997; Dunn et al., 1998; Kajermo et al.,1998; Le May, et al., 1998; Hundley et al., 2000; Kajermo et al., 2000; Parahoo, 2000; Parahoo et al., 2000; Retsas, 2000). The major barriers to research use in nursing were identified as: insufficient time to implement new ideas; lack of co-operation from physicians; lack of time to read research; and inadequate facilities to support implementation (Dunn et al., 1998).

One of the most comprehensive studies of barriers to research use is a cross-sectional survey by Funk et al., $(1991 ; 1995)$ who devised a 'barriers' scale for a research study 
Hemsley-Brown J.V. and Oplatka, I. (2005). Bridging the Research-Practice Gap: barriers and facilitators to research use among school Principals from England and Israel, International Journal of Public Sector Management, 18, 5, pp 424-446.

with a random sample of 1,989 registered nurses (including nurse managers and administrators). Items for which a consensus about face and content validity had been obtained were used to compile a scale, which was pilot tested (Funk et al., 1991).

The Barriers Scale consisted of 29 items, randomly ordered and rated using a Likert Scale. Each item was rated on a scale from 0-4 based on the degree to which the item was perceived to be a barrier (Funk et al., 1991) - 4 implied the item was a strong barrier. This instrument had been checked for reliability by a number of researchers, and was made freely available to others. The findings from studies using the barriers scale have, therefore, achieved a relatively high degree of reliability across a number of studies in the healthcare sector in several countries (Funk et al., 1991 and 1995; Dunn et al., 1998; Parahoo, 2000; and Retsas, 2000). Minor changes in wording were carried out (with permission from the originators) and the Barriers Scale research instrument was used for this comparative study. The Barriers Scale is viewed as a highly reliable instrument which has the potential to identify significant differences in the barriers to research use among different groups, e.g. the results could be compared with findings from studies of healthcare professionals; and responses can be compared from county to country, where there might be both political and cultural differences.

In view of this comparative approach, prior to presenting the methodology, some description of the cultural similarities and differences between the compared countries is provided below based on the theories devised by Hofstede (2003). 
Hemsley-Brown J.V. and Oplatka, I. (2005). Bridging the Research-Practice Gap: barriers and facilitators to research use among school Principals from England and Israel, International Journal of Public Sector Management, 18, 5, pp 424-446.

\section{Cultural dimensions}

Hofstede (2003) conducted one of the most comprehensive studies of how values in the workplace are influenced by culture (between 1967 and 1973). He developed a model that identifies four primary Dimensions to assist in differentiating cultures: Power Distance (PDI) Individualism (IDV) Masculinity - (MAS) and Uncertainty Avoidance (UAI). The Hofstede model highlights key differences between the UK and Israel for two of the four dimensions: Individualism and Uncertainty avoidance which, it is suggested may have an impact on attitudes to research use.

Firstly, whereas England is characterized by individualism, Israeli ideological values tend to emphasize the importance of collectivism, i.e., preference for group goals attainment and social cohesiveness (Mickelson, et al., 2001). Individualism (IDV) focuses on the degree the society reinforces individual or collective achievement and interpersonal relationships. The UK scores a relatively high Individualism ranking (89) indicating that individuality and individual rights are paramount within the society. A lower Individualism ranking, such as the score for Israel (34), typifies societies of a more collectivist nature with close ties between individuals. These cultures reinforce extended families and collectives where everyone takes responsibility for fellow members of their group. For example, Israeli pre-service teachers expected their first school principal to develop friendly relationships with them, and refrain from formality and remote connections (Oplatka, 2004)

There are also differences between the two cultures based on the Uncertainty Avoidance Index (UAI) which focuses on the level of tolerance for uncertainty and 
Hemsley-Brown J.V. and Oplatka, I. (2005). Bridging the Research-Practice Gap: barriers and facilitators to research use among school Principals from England and Israel, International Journal of Public Sector Management, 18, 5, pp 424-446.

ambiguity within the society - i.e. unstructured situations. Israel has a high Uncertainty Avoidance ranking (81) which indicates that the country has a low tolerance for uncertainty and ambiguity. This implies that Israel is a more ruleoriented society than the UK that institutes laws, rules, regulations, and controls in order to reduce the amount of uncertainty within the population.

The UK has a lower Uncertainty Avoidance ranking (35) indicating that the country has less concern about ambiguity and uncertainty and has more tolerance for a variety of opinions. This should reflect a society that more readily accepts change, and takes more and greater risks. Western countries tend to have a strong belief in individuality, with individual rights being paramount within the society (Hofstede (2003).

Thus, while the UK has a decentralized educational system the Israeli educational system is relatively centralized both in structure and procedure (Goldring and Sullivan, 1997). The government is the provider of education for almost everyone and all high schools are required to follow a basic national curriculum. In common with the UK system, the effectiveness of the Israeli centralized system has been questioned in recent years as new educational themes became important, such as educational diversity, decentralization and the encouragement of excellence (Hayman et al., 1997) and marketisation (Oplatka, 2002). It is in this context that principals in both countries live and work. The research methodology is presented in the following section. 
Hemsley-Brown J.V. and Oplatka, I. (2005). Bridging the Research-Practice Gap: barriers and facilitators to research use among school Principals from England and Israel, International Journal of Public Sector Management, 18, 5, pp 424-446.

\section{Research Methodology}

The purpose of this research was to examine school principals' perceptions of barriers to the use of research and to make comparisons between the two countries. The study was conducted simultaneously in two countries: England and Israel, by the authors of this paper, in mid-late 2002. A stratified random sample of 6 local districts (3 from Israel), or local authorities ( 3 from the UK) were identified in each country, for the conduct of the research and questionnaires were distributed to principals of primary (elementary) and secondary (high) schools within these districts.

\section{Qualitative research}

In Israel eight face-to-face interviews with school principals were conducted by the co-author of this paper. The interviews were semi-structured, and followed the wellestablished conventions of the qualitative paradigm (Marshall and Rossman, 1995). In the UK three focus groups were conducted by the first-named author, one in each of three local authorities (districts). The interviews, and focus groups conducted with principals lasted for one hour and were as Paton, (1990) indicated, purposeful conversations where the content and evolution were not defined a priori, so that there might be some differences between the interviews and between focus groups. Openended questions were used in both focus groups and interviews, to gain the respondents' subjective perceptions of the use of research, barriers to the use of research findings, experiences of using research findings, and suggested ways to facilitate research use. All discussions were recorded on audio-tape for later translation and analysis. The Israeli author analyzed the interview data and the verbatim transcripts were translated into English by a professional translator. 
Hemsley-Brown J.V. and Oplatka, I. (2005). Bridging the Research-Practice Gap: barriers and facilitators to research use among school Principals from England and Israel, International Journal of Public Sector Management, 18, 5, pp 424-446.

\section{Quantitative research}

The Barriers questionnaire included the list of the 29 factors previously identified as barriers to research use by Funk et al. (1991), items, rated on a four-point scale, were listed randomly, but categorised using four factor headings, barriers associated with: the individual or adopter of the research; the organisational setting or the culture and ethos of the organisation; the research itself or innovation; and presentation or communication of the research (see below). Tests to measure the reliability of these four constructs were conducted by the originators of the instrument, but results of further tests are reported below. The questionnaire was constructed in the same layout and wording used in studies by Funk et al, (1991) with minor changes to terminology to provide a focus on education (approved by the originators). The instrument was professionally translated into Hebrew prior to conducting the study in Israel. Anonymity was assured and participation was voluntary in both countries.

\section{Analysis of quantitative data}

The achieved useable sample for further analysis was 105 questionnaires: 65 from England and 40 from Israel. Factor one, the individual user of the research was concerned with the skills, awareness and research values of the individual and their willingness to use new ideas or change practice. Factor two, dealt with the setting, or characteristics of the organisation in which the research might be used, for example whether administration would allow implementation, lack of support from senior managers or other staff, insufficient time to read or to implement research, including inadequate facilities. Factor three focused on the research itself, the methodologies 
Hemsley-Brown J.V. and Oplatka, I. (2005). Bridging the Research-Practice Gap: barriers and facilitators to research use among school Principals from England and Israel, International Journal of Public Sector Management, 18, 5, pp 424-446.

used, the conclusions drawn, lack of replication or conflicting results as well as the uncertainty regarding whether to believe the results. Factor four focused on the presentation and accessibility of the research, including availability of reports, statistical analyses and communication of research findings generally. The following research hypothesis was formulated:

H1 - Principals from Israel and principals from England show differences in the perceived barriers to research use.

In order to verify the constructed hypothesis and because of the character of the research, we analysed results using SPSS Version 11. for Windows. Table I (England) and Table II (Israel) present descriptive information on the scores obtained from respondents from each country.

\section{Insert Table I here}

Visual observation of Table I indicates that the two greatest barriers to research use by respondents from England were perceived to be those associated with the setting or context - more specifically the 'time barriers': "You do not have the time to read research" $(\mathrm{M}=3.43)$; "There is insufficient time on the job to implement new ideas" $(\mathrm{M}=3.26)$. And also the research itself: "Research reports/articles are not readily available" $(\mathrm{M}=2.95)$.

The factors which were not perceived to be strong barriers related to: the setting, and to the individual. The lowest score was scored against the item: "Management will not allow implementation" $(\mathrm{M}=1.15)$ which suggests that there is perceived to be little opposition from management regarding the implementation of research findings. The findings indicated that principals in England did not believe they were "unwilling to 
Hemsley-Brown J.V. and Oplatka, I. (2005). Bridging the Research-Practice Gap: barriers and facilitators to research use among school Principals from England and Israel, International Journal of Public Sector Management, 18, 5, pp 424-446.

change/try new ideas" $(\mathrm{M}=1.29)$ nor did they challenge the "value of research for practice" $(M=1.43)$. The similarity in respect to willingness to change or to use new ideas stems from globalisation, where change rather than stagnation is supported and valued, and principals from both countries are under pressure to initiate and implement changes in their schools. They have internalised the notion that change is necessary and positive in education.

The greatest barriers for Principals from Israel were firstly, associated with the individual: "The amount of research information is overwhelming" $(\mathrm{M}=2.95)$; and to the research itself - principals believed that, "The relevant literature is not compiled in one place" ( $M=2.92)$; and "Implications for practice are not made clear" $(M=2.75)$.

\section{Insert Table II here}

The lowest scores were similar to those identified by principals from England, and related to the value of research and the "willingness to change or to use new ideas" $(\mathrm{M}=1.58)$. Barriers associated with the presentation of research were also not perceived to be strong barriers to research use: "the research has methodological inadequacies" $(\mathrm{M}=1.63)$ and "the research has not been replicated" $(\mathrm{M}=1.87)$ were only considered weak barriers. However, these mere observations required further testing through the use of inferential statistics, the results of which are presented below.

\section{Results of tests}

Prior to conducting the statistical tests, a test of normality was conducted to calculate the Kolmogorov-Smirnov statistic. Based on the aggregate scores for all Barriers Scale items, the Kolmogorv-Smirnov statistic was 0.2 which indicates that the scores 
Hemsley-Brown J.V. and Oplatka, I. (2005). Bridging the Research-Practice Gap: barriers and facilitators to research use among school Principals from England and Israel, International Journal of Public Sector Management, 18, 5, pp 424-446.

were normally distributed. Since parametric testing is more powerful, and the samples were normally distributed: Independent samples t-tests were conducted to compare differences in the mean scores for the two nationality groups.

An aggregate score for each respondent was calculated for all the Barriers Scale items and an independent t-test was conducted to compare the total barriers to research use for Israeli and English respondents. Cronbach's Alpha coefficient for the Barriers Scale on this study was 0.82 . This value is above 0.7 so the scale is considered reliable for this sample (Pallant, 2002). The results indicated that equal variances could be assumed (Levene's test result: 0.703 ) and that there was a significant difference between the scores for teachers from Israel (Mean=66.98; $\mathrm{SD}=12.14$ ) and teachers from England (Mean=60.89; $\mathrm{SD}=13.28) \mathrm{t}(103)=-2.35, \mathrm{p}=0.21$. The magnitude of the differences in the means was moderate (eta squared $=0.05$ ), based on guidelines proposed by Cohen (1988). This finding provided evidence for further enquiry to determine the nature of these differences.

Table III. Results of t-tests about here.

Independent samples t-tests were also conducted to compare the mean scores on the aggregate variables for barriers scale items related to items grouped in the four factor categories: 'the research itself', 'presentation of research', 'the setting' and 'the individual'. There was no significant difference between groups on items related to the setting, (0.265) and items related to the research itself (0.688) (results are summarised in Table III) However, the tests indicated that there was a significant difference between the two nationality groups for items: 'the individual' $(0.011)$ and 
Hemsley-Brown J.V. and Oplatka, I. (2005). Bridging the Research-Practice Gap: barriers and facilitators to research use among school Principals from England and Israel, International Journal of Public Sector Management, 18, 5, pp 424-446.

'presentation of the research' (0.012). The mean scores awarded by principals from England were significantly lower for barriers related to 'the individual' and 'presentation of the research'.

Although there were significant differences between the two nationalities for the variables: 'the individual' and 'presentation of research', the highest mean scores across both groups were for 'the research itself' (Mean=2.56), suggesting that for both groups of principals the greatest perceived barriers were percieved to be that: "the relevant literature is not compiled in one place"; "implications for practice are not made clear" and "statistical analyses are not understandable", and "research articles are not readily available". In terms of factors related to 'the research itself', therefore, these items were considered barriers to research use by principals from both countries, and there were no significant differences between the two groups in this respect.

Although teachers from England awarded high scores to items associated "time" (items 7 and 29) and the mean scores for Israel were lower, other factors associated with the setting were also considered to be barriers to research use by Israeli teachers: "the resources are inadequate for implementation" and "the results are not generalisable to your own setting". Nonetheless, the test results also showed that there was no significant difference between the two groups in terms of the barriers associated with the "setting".

Finally, a new aggregate variable was created for the individual aggregate scores for each respondent, for each barrier category (105 x 4 scores), these scores were coded to create four factor groups (Factor 1: total scores for "the individual user" and so on). 
Hemsley-Brown J.V. and Oplatka, I. (2005). Bridging the Research-Practice Gap: barriers and facilitators to research use among school Principals from England and Israel, International Journal of Public Sector Management, 18, 5, pp 424-446.

One-way between groups analysis of variance (ANOVA) was conducted to compare the difference in the barriers to research use within and between the four different factors. For example, was the mean score awarded by the respondents $(n=105)$ to factor three 'research itself', significantly different from the mean scores awarded for the other three categories? The directional hypothesis proposed is:

H2 The "research itself" is the stronger barrier to research use by school principals, compared with "the presentation of research"; "the setting" and "the individual".

The results showed that there was a statistically significant difference at the $\mathrm{p}<.05$ level in the scores for the four different factors. Post-hoc comparisons using Tukey HSD test indicated that the mean score for "the research itself" (Mean=2.57, $\mathrm{SD}=0.611$ ) was significantly different from all three of the other barrier categories (Table IV). The magnitude of the differences in the means between the four different categories of barriers to research use was moderate to large (eta squared $=0.113$ ) (Cohen, 1988).

\section{Table IV about here}

The items which were included in factor 3, "the research itself" were the following (presented in rank order by mean score): "research articles /reports are not readily available $(\mathrm{M}=2.8 ; \mathrm{SD}=0.9)$; "implications for practice are not made clear" $(\mathrm{M}=2.7$; $\mathrm{AD}=0.91)$; "statistical analyses are not understandable" (M=2.69; $\mathrm{SD}=1.05)$; "research is not relevant to practice" $(\mathrm{M}=2.35 ; \mathrm{SD}=0.94)$; "the relevant literature is not complied in one place" $(\mathrm{M}=2.59 ; \mathrm{SD}=1.29)$; and "the research is not reported clearly and readably" $(\mathrm{M}=2.26 ; \mathrm{SD}=1.18)$. A paired samples t-test was also conducted to evaluate the difference between the means scores for each pair of variables. Similarly, there was a statistically significant difference between 
Hemsley-Brown J.V. and Oplatka, I. (2005). Bridging the Research-Practice Gap: barriers and facilitators to research use among school Principals from England and Israel, International Journal of Public Sector Management, 18, 5, pp 424-446.

respondents' scores for "the research itself" and the other three factors, where the mean scores for "the research itself" were higher.

\section{Additional barriers}

Each respondent was asked to add up to three additional barriers, which were categorised during the analysis. However, factors listed as 'barriers' by the respondents from England, were all variations on the same items already used in the survey, and were subsequently categorised as such. These related to: access; time; relevance; and availability of resources. Many respondents, however, listed factors which were 'facilitators', rather than barriers. Four categories emerged as a way of analysing these additional factors: training issues, e.g. in-service training, conferences or research sabbaticals; presentation of research issues, e.g. more media coverage, free journals and greater use of the Internet. Respondents also highlighted the need to change the culture so that research was valued, and suggestions included a change in climate which supported greater ownership by practitioners and increased status.

Principals from Israel also suggested additional items that had already been covered in the survey: access issues e.g. difficulties in finding relevant research; the complexity of research, e.g. lack of necessary skills to understand the findings; the belief that there was so much research that identifying a useful study was difficult; resources e.g. time and training issues needed to be prioritised and principals were not required to access research. 
Hemsley-Brown J.V. and Oplatka, I. (2005). Bridging the Research-Practice Gap: barriers and facilitators to research use among school Principals from England and Israel, International Journal of Public Sector Management, 18, 5, pp 424-446.

\section{Analysis of qualitative data}

The analysis of interview and focus group data followed the stages described by Marshall and Rossman (1995) 'organising data', 'generating categories, themes and patterns' 'testing any emergent hypotheses' and 'searching for alternative explanations'. The analysis aimed to identify the central themes emerging from the data and to this end data was coded and collated using a grid to enable recurrent experiences and themes to be identified.

\section{Barriers to research use}

Analysis of qualitative data indicated that consistent with previous research, e.g. Funk et al (1995) the following factors were identified as major barriers to research use in both Israel and England: limited time; accessibility and lack of exposure to research; relevance and fitness for purpose; and lack of encouragement or support. In both countries the research itself was identified as a barrier, based on the perception that research tended to produce contradictory results. This supports the results which emerged from statistical testing. In England, there was a concern that research evidence should fit within the measurement culture of schools. Principals from Israel identified 'information inflation' as a barrier, and one principal argued that 'lack of curiosity' might also be a barrier for some.

However, in England, two additional themes emerged which were not identified in

Israel. Principals believed that political and personal reasons prevented them from seeking and using research evidence to support their decision-making. Political reasons were broadly those that related to government pressure, and top-down decision-making. Principals argued that they worked in a culture whereby the 
Hemsley-Brown J.V. and Oplatka, I. (2005). Bridging the Research-Practice Gap: barriers and facilitators to research use among school Principals from England and Israel, International Journal of Public Sector Management, 18, 5, pp 424-446.

government forced initiatives on schools, whether or not the ideas were supported by research evidence. Their perception was that this left no room for initiating and implementing ideas based on their own research, or the evidence from published research. Principals from England also expressed concern that they were personally not experienced enough as researchers to interpret the findings from research or to translate the evidence into classroom settings. Political interference or concerns about political intervention did not emerge from data collected through interviews with Israeli principals.

\section{Facilitating research use}

Principals from both countries described and analysed experiences that had contributed towards greater research use within their personal experience. They suggested that research should be: relevant - principals were interested mainly in 'what works' in the classroom and they concentrated on contextual factors associated with the research such as accessible, and dissemination to schools. Principals from England suggested that summaries of research had been helpful, and the language needed to be accessible. The importance of pre-service training, and continuing professional development was also mentioned by principals from both countries. Principals from England were particularly concerned about 'ownership' and the need for research use to be valued, credited, and well resourced. The importance of collaboration and sharing was highlighted by principals from both countries. Principals viewed themselves as partners in the process of using research and they used the terms 'sharing' and 'sharing good practice'. Principals from England believed that using research could bring about a culture change, but research had to be valued by those who monitored and inspected schools. 
Hemsley-Brown J.V. and Oplatka, I. (2005). Bridging the Research-Practice Gap: barriers and facilitators to research use among school Principals from England and Israel, International Journal of Public Sector Management, 18, 5, pp 424-446.

\section{Discussion of results}

First, the findings indicate that there is a moderate significant difference between principals from Israel and Principals from England regarding barriers to the use of research. These differences were identified at those relating to "the individual" and "presentation of the research", where the barriers were stronger for principals in Israel, than for principals in England, for both factors. Factor one, "the individual" related to the willingness to change and to try new ideas, and lack of recognition of the benefits of changing practice. Awareness of the research and access to knowledgeable colleagues with whom to discuss the research was also a barrier. The highest mean score was for the barrier item "The amount of research information is overwhelming", indicating that rather than a lack of information, principals perceived that there was too much information. Factor four 'presentation of research' items related to uncertainty about whether to believe the results for example, whether they were conflicting, reliable, valid and up-to-date. These factors were perceived to be moderately stronger barriers for principals from Israel compared with principals from England. This significant difference is only moderate, and may stem from a culture of teaching and similar schooling processes that cross national borders i.e. a universal professional code. This may mean that professionals from the same occupation worldwide tend to share similar experiences and assumptions that lead to them feeling and reporting having similar barriers to research utilisation. Perhaps future international research might focus on the organisational level rather than the individual level. 
Hemsley-Brown J.V. and Oplatka, I. (2005). Bridging the Research-Practice Gap: barriers and facilitators to research use among school Principals from England and Israel, International Journal of Public Sector Management, 18, 5, pp 424-446.

Although principals from England (particularly in the qualitative research study) were very concerned about the "time" to access and to use research, barriers associated with time (i.e. the "setting") were not significantly different between the two countries based on the findings from the quantitative study. This similarity could be explained by the large-scale reforms that have taken place in England and in Israel which have intensified the principal's role and contributed to severe pressure and perceptions of work overload.

Secondly, the key barriers to research use for principals from both countries were perceived to be aspects of "the research itself" and the test results indicated that these barriers were perceived to be significantly stronger than other barriers. These factors included the view that research articles were not readily available, or understandable, and that the implications for practice were rarely made clear. Lack of relevance of research and the belief that findings from research were not compiled in one place, were also items included in the factor "the research itself", on the Barrier Scale used for the survey. The perceptions of the lack of relevance of research could derive from the uncertain, ambiguous nature of teaching and schooling that makes it difficult for researchers to identify clear, valid principles and findings based on hard evidence. Teaching is more of a craft than a science (Orenstein, 1989). These findings also demonstrate that the key barriers to research use by principals from these two countries are different from those identified by healthcare professionals, where issues related to "the setting" were perceived to be the strongest barriers (Dunn et al. 1998). Our conclusion, is that research utilisation in 'uncertain' e.g. social science professions and occupations is less likely to be high (e.g. law, social work), while in 
Hemsley-Brown J.V. and Oplatka, I. (2005). Bridging the Research-Practice Gap: barriers and facilitators to research use among school Principals from England and Israel, International Journal of Public Sector Management, 18, 5, pp 424-446.

more 'structured' occupations such as healthcare (nursing and medicine) one could expect higher levels of research utilisation.

Thirdly, respondents were asked to report on the ways that research use could be facilitated. Principals identified training issues, and suggested that in-service training, conferences or research sabbaticals could address the issues. They also focused on presentation issues and suggested greater media coverage, access to free journals and greater use of the Internet. These ideas have appeal, and appear to provided ways of addressing the barriers from the perspectives of potential users, however, would they address the key barriers identified in the survey i.e. the relevance; volume of evidence; apparent conflicting evidence; in addition to the barrier of statistical approaches used for analysis? Respondents also highlighted the need to change the culture so that research was valued in the context of education. Factors associated with "the setting", however, such as the culture were not significant barriers compared with "the research itself", in either country.

The items which make up this factor, to some extent highlight the "gap" that has been identified by others. These items are issues which illustrate the differences in goals between those who carry out research, and those who might implement the findings. First, the issue of relevance highlights the tendency for decisions about research questions to be initiated by the researchers themselves, and/or by funding bodies, and government, rather than by the users. Secondly, the problem of conflicting evidence is an issue which both users and researchers seem to be aware of, whereas clinical researchers can conduct experiments and control variables, this is far more complex in 
Hemsley-Brown J.V. and Oplatka, I. (2005). Bridging the Research-Practice Gap: barriers and facilitators to research use among school Principals from England and Israel, International Journal of Public Sector Management, 18, 5, pp 424-446.

the social sciences, where the variables can rarely be isolated and the research takes place in a social setting.

However, the time and training issues suggested by principals themselves perhaps, need to be given serious consideration as a way of providing greater access to research and as a way of creating opportunities for principals to engage with research and facilitating greater understanding of the "research itself". For example, the suggestion that greater 'ownership' could improve research use, and that there was a need for research use to be valued, credited, and well resourced, provide possible strategies for improving knowledge and understanding of the "research itself". The importance of collaboration and sharing was also highlighted by principals from both countries but this might be viewed perhaps as a way of supporting greater understanding of the research itself.

\section{Conclusion}

One of the key items highlighted in this study, and in previous studies is the relevance of research to practice (which was one item in the "research itself" construct) principals interpreted the notion of research use as "what works" which suggested that there understanding of "research use" was essentially instrumental. However, to some extent this interpretation was one of the limitations of this study, in that the implied meaning of the "term research use" may have focused on the instrumental interpretation of the term. Exploring the different meanings and interpretations of "research use" would need to be the subject of further research. 
Hemsley-Brown J.V. and Oplatka, I. (2005). Bridging the Research-Practice Gap: barriers and facilitators to research use among school Principals from England and Israel, International Journal of Public Sector Management, 18, 5, pp 424-446.

Due to the similarities, and the dissimilarities between the two nations' principals, the authors might be permitted to speculate, therefore, that lack of time may not be the only barrier to research use among principals, even though principals from England indicated strongly that this was their greatest problem. Research evidence suggests that if more time were available, other barriers might still prevent principals from using research to support practice. The barriers associated with the research itself, for example "relevance to practice" would need to be addressed in addition to creating time and opportunities to engage with research.

Principals from Israel indicated that support from colleagues was a key issue and a move towards a more collaborative culture where educationalists worked together with researchers to bridge the gap between research and teaching was suggested. Multiple strategies would be required to bridge the gap between the aims of research and the pressures on researchers, and the needs and expectations of the practitioners. However, such strategies are un-tested in the field and further research is needed to provide empirical evidence of the impact of such approaches.

words $6,086+$ tables

\section{References}

Barta, K. (1995). Information-seeking, research utilisation, and barriers to research utilisation of paediatric nurse educators, Journal of Professional Nursing, Vol. 11 No. 1, pp. 49-57.

Bassett, C. (1992). The integration of research in the clinical setting: obstacles and solutions. A review of the literature, Nursing Practice, Vol. 6 No. 1, pp. 4-8.

Bassey, M. (1992). Creating education through research, British Educational Research Journal, Vol. 18 No. 1, pp. 3-16. 
Hemsley-Brown J.V. and Oplatka, I. (2005). Bridging the Research-Practice Gap: barriers and facilitators to research use among school Principals from England and Israel, International Journal of Public Sector Management, 18, 5, pp 424-446.

Biddle, B. J., and Saha, L. J. (2000). Research knowledge use and school principal', Paper presented at the American Educational Research Association's Annual Meeting, New Orleans, April 24, 2000.

Bostrum, J. and Suter, W.N. (1993). Research utilisation: making the link to practice, Journal of Nursing Staff Development, Vol. 9, Jan/Feb, pp. 28-34.

Bryant, A. (2000). Information wanted? Knowledge, curiosity, uncertainty and evidence; a qualitative study of the perceived information needs of general practitioners, Paper presented at the Qualitative Evidence-Based Practice Conference Coventry University, May 15-17 [online] Available: http://www.leeds.ac.uk/educol/documents/00001417.htm.

Camiah, S. (1997). Utilisation of nursing research in practice and application strategies to raise research awareness amongst nurse practitioners: a model for success, Journal of Advanced Nursing, Vol. 26 No. 6, pp. 1193-1202.

Castle, S.D. (1988). Empowerment through knowledge, in S.D. Castle, (Ed). Teacher empowerment through knowledge linking research and practice for school reform Papers presented at the Annual Meeting of the American Educational Research Association, , April 5-9.

Champion, V.L. and Leach, A. (1989). Variables related to research utilisation in nursing: An empirical study, Journal of Advanced Nursing, Vol. 14, pp. 705-710.

Closs, S. and Cheater, F. (1994). Utilisation of nursing research: culture, interest and support, Journal of Advanced Nursing, Vol. 19 No. 4, pp. 762-773.

Cohen, J. (1988). Statistical Power analysis for the behavioural Sciences, Hillsdale, NJ. Erlbaum.

Cousins, J. and Leithwood, K. (1993). Enhancing knowledge utilisation as a strategy for school improvement, Knowledge Creation Diffusion Utilisation, Vol. 14 No. 3, pp. 305-333.

Deforges, C. (2000). Familiar challenges and new approaches: necessary advances in theory and methods in research on teaching and learning, Conference, The Desmond Nuttall/Carfax Memorial Lecture, British Educational Research Association Annual, Cardiff University, September 7-10, 2000.

Dimmock, C. and Walker, A. (1998). Comparative Educational Administration: Developing a Cross-Cultural Conceptual Framework, Educational Administration Quarterly, Vol. 34, 4, (November 1998). pp.558-95.

Dobby, J., (1999). 'Issues of Quality in Research Review: lessons to be drawn from the experience of the evidence-based health care movement', Paper Presented at the Annual General Meeting of The National Foundation For Education Research, 13 October 2000. 
Hemsley-Brown J.V. and Oplatka, I. (2005). Bridging the Research-Practice Gap: barriers and facilitators to research use among school Principals from England and Israel, International Journal of Public Sector Management, 18, 5, pp 424-446.

Dunn, S., Crichton, N. Roe B., Seers, K., and Williams, K. (1998). Using research for practice: a UK experience of a BARRIERS scale, Journal of Advanced Nursing, Vol. 26 6, pp. 1203-1210.

Fleming, D.S. (1988). The Literature on Teacher Utilisation of Research: Implications for the School Reform Movement', in S.D. Castle (Ed). Teacher empowerment through knowledge linking research and practice for school reform, Papers presented at the Annual Meeting of the American Educational Research Association , April 5-9 1988.

Funk, S.G., Champagne, M.T., Wiese, R.A. and Tornquist, E.M. (1991). Barriers: the barriers to research utilisation scale, Applied Nursing Research, Vol. 4 No. 1, pp. 39 45 .

Funk, S., Champagne, M., Tornquist, E. and others (1995). Administrators' views on barriers to research Utilisation, Applied Nursing Research, Vol. 8 No. 1, pp.44-9.

Goldring, E.B., and Sullivan, A.V. (1997). Beyond the Boundaries: Principals, Parents and Communities Shaping the School Environment, in K. Leithwood, J. Chapman, D., Corson, P., Hallinger, and A. Hart, (Eds.)'International Handbook of Educational Leadership and Administration, Dordrecht, Kluwer Academic, 1997, pp. $195-222$.

Hallinan, Maureen T. (1996). Bridging the gap between research and practice. Sociology of Education, [Special Issue] pp.131-134.

Hannan, A., Enright, H. and Ballard, P. (2000), "Using research: the results of a pilot study comparing teachers, general practitioners and surgeons", Education-Line Internet Collection, Leeds. http://www.leeds.ac.uk/educol/documents/000000851.htm (Accessed October 2004).

Hargreaves, D. (1996). Teaching as a research-based profession: possibilities and prospects, Teacher Training Agency Annual Lecture, London: Teacher Training Agency.

Hammersley, M. (2000). 'Media representation of social and educational research: the case of a review of ethnic minority education', Paper presented at the British Educational Research Association Annual Conference, Cardiff University, September 7-10 [online] Available: http://www. leeds.ac.uk/educol/documents/00001499.htm

Hayman, F., Golan, H. and Shapira, R. (1997). School Autonomy and Parental Choice: Steps in Local Educational Planning, in R. Shapira and P. W. Cookson, (Ed.) Autonomy and Change in Context: An International Perspective, Oxford: Pergamon pp. 77-108.

Hemsley-Brown, J. V. (2004). "Facilitating Research Utilisation: a cross sector review of the research evidence, International Journal of Public Sector Management, Vol. 17 No. 6. (forthcoming) 
Hemsley-Brown J.V. and Oplatka, I. (2005). Bridging the Research-Practice Gap: barriers and facilitators to research use among school Principals from England and Israel, International Journal of Public Sector Management, 18, 5, pp 424-446.

Hemsley-Brown, J. V. and Sharp C. (2002). 'The use of research by practitioners in education: has medicine got it cracked?', Paper Presented to the British Education Research Association Conference, University of Exeter, 12th - 14th September 2002.

Hemsley-Brown, J.V., and Sharp, C. (2003). The Use of Research to Improve Professional Practice: a systematic review of the literature, Oxford Review of Education, Vol. 29 No. 4, December 2003, pp.449-70.

Higher Education Funding Council for England (HEFCE) (1999), Research Activity Survey, http://www.hefce.ac.uk/pubs/hefce/1999/99_59.htm [October, 2004].

Hillage, J. Pearson, R. Anderson, A. and Tamkin, P. (1998). Hillage Report. Excellence in Research on Schools, Institute for Employment Studies, [DfEE Research Reports RR74], London, DfEE.

Hofstede, G. (2003). Cultural Dimensions', Available [on-line] at: http://www.geerthofstede.com/geert_hofstede_resources.shtml (accessed: September 30th 2003).

Huberman, M. (1993). 'Linking the practitioner and researcher communities for school improvement", School Effectiveness and School Improvement, Vol. 4 No. 1, pp. 1-16.

Hundley, V., Milne, J., Leighton-Beck et al. (2000). Raising research awareness among midwives and nurses: does it work? Journal of Advanced Nursing, Vol. 31 No. 1, pp. $78-88$.

Hunt, M. (1996). Barriers to research utilisation, Journal of Advanced Nursing, Vol. 23 No. 3, pp. 423-25.

Iram, Y. and Schmida, M. (1998). The Educational System of Israel, (Westport, Conn: Greenwood).

Kajermo, K. Nordstrom, G. and Krusebrant, A. et al. (1998). Barriers to and facilitators of research utilisation, as perceived by a group of registered nurses in Sweden, Journal of Advanced Nursing, Vol. 27 No. 4, pp.798-807.

Kajermo, K. Nordstrom, G. Krusebrant A, et al. (2000). Perceptions of research utilisation: comparisons between health care professionals, nursing students and a reference group of nurse clinicians, Journal of Advanced Nursing, Vol. 31 No. 1, 99109.

Klein, S.S. (1993). 'Sharing the best: Finding better ways for the federal government to use evaluation to guide the dissemination of promising and exemplary education solutions', Evaluation Program Planning, Vol. 16 No. 3, 213-17. 
Hemsley-Brown J.V. and Oplatka, I. (2005). Bridging the Research-Practice Gap: barriers and facilitators to research use among school Principals from England and Israel, International Journal of Public Sector Management, 18, 5, pp 424-446.

Klein, S.S. (1993). 'Are there better ways to identify and share the best within and among federal education-programs', Evaluation Program Planning, Vol. 16 No. 3, 227-39.

Lacey, E. (1994). Research utilisation in nursing practice: a pilot study, Journal of Advance Nursing, Vol. 19 No. 5, pp. 987-95.

Lacey, E. (1996). Facilitating research-based practice by educational intervention, Nurse Education Today, Vol. 16 No. 4, pp. 296-301.

Latham, G. (1993), "Do educators use the literature of the profession?", National Association of Secondary School Principals Bulletin, Vol. 77 No. 550, pp.63-70.

Le May, A., Mulhall, A., and Alexander, C. (1998). Bridging the research -practice gap: exploring the research cultures of practitioners and managers', Journal of Advanced Nursing, Vol. 28 No. 2, 428-37.

Louis, K.S. (1992). 'Comparative perspectives on dissemination and knowledge use policies: supporting school improvement', Knowledge, Creation, Diffusion, Utilisation, Vol. 13 No. 3, 287-304.

Louis, K.S. (1996). Reconnecting knowledge utilisation and school improvement: two steps forward, one step back, in: A. Hargreaves, M. Fullan and D. Hopkins (Eds) International Handbook on School Improvement, London, Cassell.

Louis, K.S., Dentler, R. And Kell, D. (1985). 'Putting knowledge to work' A final synthesis report, The National Institute of Education, Massachusetts).

Maccoll, G., and White, K. (1996). Improving the utility of educational research for policymakers, Paper presented at the Annual Meeting of the American Educational Research Association, April 8-12.

Macguire, J. (1990). Putting nursing research findings into practice: research utilisation as an aspect of the management of change, Journal of Advanced Nursing, Vol. 15 No. 5, pp. 614-20.

Malouf, D., Schiller, E. (1995). Practice and research in special education, Exceptional Children, Vol. 61 No. 5, 414-24.

Marshall, C. and Rossman, G. (1995). Designing qualitative research (2nd Ed.). London, Sage Publications.

Meah, S. Luker K., and Cullum, N. (1996). An exploration of midwives' attitudes to research and perceived barriers to research utilisation, Midwifery, Vol. 12 No. 2, pp.73-84.

Mickelson, R. A., Nkomo, M. and Smith, S.S. (2001). Education, Ethnicity, Gender and Social Transformation in Israel and South Africa, Comparative Education Review, Vol. 45 No. 1, pp. 1-35. 
Hemsley-Brown J.V. and Oplatka, I. (2005). Bridging the Research-Practice Gap: barriers and facilitators to research use among school Principals from England and Israel, International Journal of Public Sector Management, 18, 5, pp 424-446.

Moore, P.A. (1995). The utilisation of research in practice, Professional Nurse, Vol. 10 No. 8, pp. 536-7.

National Center For The Dissemination Of Disability Research (NCDDR) (2000). 'Review of the literature on dissemination and knowledge utilisation', [online] Available: http://www.ncddr.org/du/products/review/ (Accessed, September 2004).

Oplatka, I. (2002). The emergence of educational marketing: lessons from the experiences of Israeli principals, Comparative Education Review, Vol. 46 No. 2, pp. 211-233.

Oplatka, I. (2004). Prospective teachers' constructions of leadership: In search of an 'androgynous' style, Leadership and Policy in Schools, Vol. 3 No. 1, pp.37-57.

Ornstein, A.C. (1989). Theoretical issues related to teaching. Education and Urban Society, Vol. 22 No. 1, 95-104.

Pallant, J. (2002). SPSS Survival Manual: a step by step guide to data analysis using SPSS, Milton Keynes, Open University Press.

Parahoo, K. (2000). Barriers to, and facilitators of, research utilisation among nurses in Northern Ireland, Journal of Advanced Nursing, Vol. 31 No. 1, pp.89-98.

Parahoo, K., Barr, O., and Mccaughan, E. (2000). Research utilisation and attitudes towards research among learning disability nurses in Northern Ireland, Journal of Advanced Nursing, Vol. 31 No. 3, pp. 607-613.

Paton, M. Q. (1990). Qualitative Evaluation and Research Methods, 2nd ed. (Newbury Park, Calif., Sage) pp. 81-102.

Rauch, S. (1991). Translating research into action, New York: EDRS Paper.

Retsas, A. (2000). Barriers to using research evidence in nursing practice, Journal of Advanced Nursing, Vol. 31 No. 3, pp. 599-606.

Rodgers, S. (1994). An exploratory study of research utilisation by nurses in general medical and surgical wards', Journal of Advanced Nursing, Vol. 20 No. 5, pp. 904-11.

Rodgers, S. (2000). The extent of nursing research utilisation in general medical and surgical wards', Journal of Advanced Nursing, Vol. 32 No. 1, pp. 182-93.

Saha, L. Biddle, B. and Anderson, D. (1995). Attitudes towards education research knowledge and policymaking among American and Australian school principals, International Journal of Educational Research, Vol. 23 No. 2, pp. 113-126.

Schmitt, M. (1999). Closing the gap between research and practice: strategies to enhance research utilisation, Research in Nursing Health, Vol. 22 No. 6, pp. 433-34. 
Hemsley-Brown J.V. and Oplatka, I. (2005). Bridging the Research-Practice Gap: barriers and facilitators to research use among school Principals from England and Israel, International Journal of Public Sector Management, 18, 5, pp 424-446.

Shkedi, A. (1998). Teachers' attitudes towards research: a challenge for qualitative researchers, International Journal of Qualitative Studies in Education, Vol. 11 No. 4, pp. 559-77.

Staller, K. and Kirk, S. (1998). Knowledge utilisation in social work and legal practice, Journal of Sociology and Social Welfare, Vol. 25, p. 3.

Stenhouse, L. (1987), "The study of sample cases" in Murphy, R. and Torrance, H. (Eds.), Evaluating Education, Issues and Methods, An Open University Reader, Paul Chapman Publishing, London, pp 74-81.

Tierney, W.G. (2000). On translation: from research findings on public utility, Theory into Practice, Vol. 39 No. 3, pp. 185-90.

Turnbull, B. (1992). Research knowledge and school improvement: can this marriage be saved? Paper presented at the Annual Meeting of the American Educational Research Association, April 20-24.

Walter, I., Nutley, S. and Davies, H. (2003). 'Research Impact: a cross sector literature review', Research Unit for Research Utilisation, University of St. Andrews. Available [online] at: http://www.standrews.ac.uk/ cppm/LSDA\%20literature\%20review\%20final.pdf (Accessed: 6 July 2004).

Wilson, R., Hemsley-Brown, J., Easton, C. and Sharp, C. (2003). Using Research for School Improvement: The LEA's Role, (Slough, NFER).

Winter, J.C. (1990). Brief: relationships between sources of knowledge and use of research findings, Journal of Continuing Education in Nursing, Vol. 21 No. 3, pp. 138-140. 
Hemsley-Brown J.V. and Oplatka, I. (2005). Bridging the Research-Practice Gap: barriers and facilitators to research use among school Principals from England and Israel, International Journal of Public Sector Management, 18, 5, pp 424-446.

Table I. Barriers to the use of research - England

\begin{tabular}{|c|c|c|c|c|c|c|c|c|}
\hline & $\begin{array}{c}\text { Item } \\
\text { no. }\end{array}$ & Item & $\begin{array}{l}\text { To no } \\
\text { extent }\end{array}$ & $\begin{array}{l}\text { To a } \\
\text { little } \\
\text { extent } \\
\end{array}$ & \begin{tabular}{|c|} 
To a \\
moderate \\
extent
\end{tabular} & \begin{tabular}{|c|} 
To a \\
great \\
extent
\end{tabular} & $\begin{array}{c}\text { No } \\
\text { opinion }\end{array}$ & Mean \\
\hline $\mathrm{s}$ & 7 & You do not have the time to read research & 3 & 6 & 16 & 40 & 0 & 3.43 \\
\hline s & 29 & $\begin{array}{l}\text { There is insufficient time on the job to } \\
\text { implement new ideas }\end{array}$ & 5 & 10 & 13 & 37 & 0 & 3.26 \\
\hline $\mathrm{r}$ & 1 & $\begin{array}{l}\text { Research reports/articles are not readily } \\
\text { available }\end{array}$ & 2 & 11 & 36 & 15 & 1 & 2.95 \\
\hline $\mathrm{r}$ & 3 & Statistical analyses are not understandable & 4 & 21 & 18 & 19 & 3 & 2.71 \\
\hline$r$ & 2 & $\begin{array}{l}\text { Implications for practice are not made } \\
\text { clear }\end{array}$ & 3 & 16 & 33 & 10 & 3 & 2.68 \\
\hline $\mathrm{i}$ & 27 & $\begin{array}{l}\text { The amount of research information is } \\
\text { overwhelming }\end{array}$ & 5 & 13 & 24 & 17 & 6 & 2.63 \\
\hline s & 6 & $\begin{array}{l}\text { The resources are inadequate for } \\
\text { implementation }\end{array}$ & 2 & 19 & 19 & 18 & 7 & 2.60 \\
\hline 1 & 5 & You are unaware of the research & 6 & 17 & 19 & 17 & 6 & 2.54 \\
\hline $\mathrm{r}$ & 12 & $\begin{array}{l}\text { The relevant literature is not compiled in } \\
\text { one place }\end{array}$ & 2 & 15 & 21 & 15 & 12 & 2.38 \\
\hline $\mathrm{i}$ & 28 & $\begin{array}{l}\text { You do not feel capable of evaluating the } \\
\text { quality of research }\end{array}$ & 12 & 18 & 23 & 9 & 3 & 2.35 \\
\hline $\mathrm{r}$ & 4 & $\begin{array}{l}\text { The research is not relevant to your } \\
\text { practice }\end{array}$ & 9 & 23 & 26 & 4 & 3 & 2.29 \\
\hline $\mathrm{r}$ & 24 & $\begin{array}{l}\text { The research is not reported clearly and } \\
\text { readably }\end{array}$ & 6 & 21 & 25 & 6 & 7 & 2.26 \\
\hline $\mathrm{s}$ & 14 & $\begin{array}{l}\text { You feel the results are not generalizable } \\
\text { to own setting }\end{array}$ & 12 & 22 & 20 & 7 & 4 & 2.22 \\
\hline $\mathrm{i}$ & 9 & $\begin{array}{l}\text { You feel the benefits of changing practice } \\
\text { will be minimal }\end{array}$ & 7 & 28 & 24 & 2 & 4 & 2.2 \\
\hline $\mathrm{p}$ & 10 & $\begin{array}{l}\text { You are uncertain whether to believe the } \\
\text { results of the research }\end{array}$ & 10 & 29 & 14 & 6 & 6 & 2.06 \\
\hline $\mathrm{p}$ & 23 & The literature reports conflicting results & 8 & 19 & 19 & 6 & 13 & 1.95 \\
\hline $\mathrm{i}$ & 15 & $\begin{array}{l}\text { You are isolated from knowledgeable } \\
\text { colleagues with whom to discuss the } \\
\text { research }\end{array}$ & 24 & 18 & 15 & 4 & 4 & 1.86 \\
\hline $\mathrm{i}$ & 16 & You see little benefit for yourself & 26 & 19 & 14 & 2 & 4 & 1.75 \\
\hline s & 18 & $\begin{array}{l}\begin{array}{l}\text { Colleague will no cooperate } \\
\text { implementation }\end{array} \\
\end{array}$ & 22 & 26 & 8 & 3 & 6 & 1.69 \\
\hline $\mathrm{s}$ & 25 & $\begin{array}{l}\begin{array}{l}\text { Other staff are not supportive of } \\
\text { implementation }\end{array} \\
\end{array}$ & 22 & 28 & 8 & 2 & 5 & 1.69 \\
\hline $\mathrm{p}$ & 17 & $\begin{array}{l}\text { Research reports/articles are not published } \\
\text { fast enough }\end{array}$ & 10 & 18 & 10 & 8 & 19 & 1.66 \\
\hline $\mathrm{p}$ & 8 & The research has not been replicated & 5 & 12 & 18 & 6 & 24 & 1.65 \\
\hline i & 21 & $\begin{array}{l}\text { There is not a documented need to change } \\
\text { practice }\end{array}$ & 19 & 21 & 11 & 3 & 11 & 1.63 \\
\hline $\mathrm{p}$ & 22 & $\begin{array}{l}\text { The conclusions drawn from the research } \\
\text { are not justified }\end{array}$ & 13 & 30 & 8 & 2 & 12 & 1.62 \\
\hline $\mathrm{p}$ & 11 & $\begin{array}{l}\text { The research has methodological } \\
\text { inadequacies }\end{array}$ & 6 & 19 & 12 & 4 & 24 & 1.48 \\
\hline $\mathrm{s}$ & 13 & $\begin{array}{l}\text { You do no feel you have enough authority } \\
\text { to change your teaching }\end{array}$ & 38 & 15 & 9 & 0 & 3 & 1.46 \\
\hline i & 20 & $\begin{array}{l}\text { You do not see the value of research for } \\
\text { practice }\end{array}$ & 41 & 13 & 6 & 2 & 3 & 1.43 \\
\hline $\mathrm{i}$ & 26 & You are unwilling to change/try new ideas & 50 & 10 & 2 & 2 & 1 & 1.29 \\
\hline $\mathrm{s}$ & 19 & Management will not allow implementation & 45 & 12 & 2 & 0 & 6 & 1.15 \\
\hline
\end{tabular}


Hemsley-Brown J.V. and Oplatka, I. (2005). Bridging the Research-Practice Gap: barriers and facilitators to research use among school Principals from England and Israel, International Journal of Public Sector Management, 18, 5, pp 424-446.

Table II. Barriers to the use of research - Israel

\begin{tabular}{|c|c|c|c|c|c|c|c|c|}
\hline & $\begin{array}{l}\text { Item } \\
\text { no. }\end{array}$ & Item & $\begin{array}{l}\text { No } \\
\text { opinion }\end{array}$ & $\begin{array}{l}\text { To no } \\
\text { extent }\end{array}$ & \begin{tabular}{|l|} 
To a \\
little \\
extent
\end{tabular} & $\begin{array}{l}\text { To a } \\
\text { moderate } \\
\text { extent }\end{array}$ & $\begin{array}{l}\text { To a great } \\
\text { extent }\end{array}$ & Mean \\
\hline & 27 & $\begin{array}{l}\text { The amount of research information } \\
\text { is overwhelming }\end{array}$ & 2 & 3 & 6 & 13 & 16 & 2.95 \\
\hline $\mathrm{r}$ & 12 & $\begin{array}{l}\text { The relevant literature is not compiled } \\
\text { in one place }\end{array}$ & 2 & 2 & 6 & 17 & 13 & 2.92 \\
\hline $\mathrm{r}$ & 2 & $\begin{array}{l}\text { Implications for practice are not made } \\
\text { clear }\end{array}$ & 0 & 2 & 15 & 14 & 9 & 2.75 \\
\hline $\mathrm{r}$ & 3 & 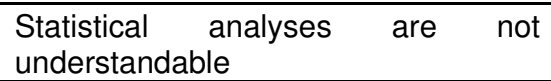 & 1 & 4 & 11 & 16 & 8 & 2.65 \\
\hline$s$ & 6 & $\begin{array}{l}\text { The resources are inadequate for } \\
\text { implementation }\end{array}$ & 1 & 3 & 12 & 18 & 6 & 2.63 \\
\hline$p$ & 17 & $\begin{array}{l}\text { Research reports/articles are not } \\
\text { published fast enough }\end{array}$ & 5 & 2 & 5 & 21 & 7 & 2.58 \\
\hline$r$ & 1 & $\begin{array}{l}\text { Research reports/articles are not } \\
\text { readily available }\end{array}$ & 0 & 8 & 8 & 18 & 6 & 2.55 \\
\hline & 15 & $\begin{array}{l}\text { You are isolated from knowledgeable } \\
\text { colleagues with whom to discuss the } \\
\text { research }\end{array}$ & 2 & 6 & 11 & 10 & 11 & 2.55 \\
\hline $\mathrm{i}$ & 5 & You are unaware of the research & 1 & 7 & 8 & 18 & 6 & 2.53 \\
\hline $\mathrm{r}$ & 4 & $\begin{array}{l}\text { The research is not relevant to your } \\
\text { practice }\end{array}$ & 1 & 4 & 16 & 14 & 5 & 2.51 \\
\hline $\mathrm{s}$ & 14 & $\begin{array}{l}\text { You feel the results are not } \\
\text { generalizable to own setting }\end{array}$ & 4 & 3 & 9 & 19 & 5 & 2.45 \\
\hline $\mathrm{p}$ & 23 & $\begin{array}{l}\text { The literature reports conflicting } \\
\text { results }\end{array}$ & 8 & 0 & 8 & 15 & 9 & 2.43 \\
\hline s & 7 & $\begin{array}{l}\text { You do not have the time to read } \\
\text { research }\end{array}$ & 1 & 4 & 18 & 11 & 6 & 2.43 \\
\hline p & 10 & $\begin{array}{l}\text { You are uncertain whether to believe } \\
\text { the results of the research }\end{array}$ & 1 & 9 & 11 & 15 & 4 & 2.3 \\
\hline$\underline{s}$ & 25 & $\begin{array}{l}\text { Other staff are not supportive of } \\
\text { implementation }\end{array}$ & 5 & 4 & 12 & 13 & 6 & 2.28 \\
\hline $\mathrm{i}$ & 9 & $\begin{array}{l}\text { You feel the benefits of changing } \\
\text { practice will be minimal }\end{array}$ & 4 & 5 & 11 & 16 & 4 & 2.28 \\
\hline$s$ & 18 & $\begin{array}{l}\text { Colleague will not cooperate with } \\
\text { implementation }\end{array}$ & 6 & 2 & 11 & 18 & 3 & 2.25 \\
\hline$r$ & 24 & $\begin{array}{l}\text { The research is not reported clearly } \\
\text { and readably }\end{array}$ & 5 & 3 & 13 & 15 & 4 & 2.25 \\
\hline$s$ & 29 & $\begin{array}{l}\text { There is insufficient time on the job to } \\
\text { implement new ideas }\end{array}$ & 0 & 9 & 18 & 8 & 5 & 2.23 \\
\hline i & 28 & $\begin{array}{l}\text { You do not feel capable of evaluating } \\
\text { the quality of research }\end{array}$ & 5 & 2 & 19 & 8 & 6 & 2.2 \\
\hline$s$ & 19 & $\begin{array}{llll}\begin{array}{l}\text { Management } \\
\text { implementation }\end{array} & \text { will } & \text { not } & \text { allow } \\
\end{array}$ & 2 & 10 & 12 & 12 & 4 & 2.15 \\
\hline p & 22 & $\begin{array}{l}\text { The conclusions drawn from the } \\
\text { research are not justified }\end{array}$ & 7 & 3 & 15 & 8 & 7 & 2.13 \\
\hline$i$ & 16 & You see little benefit for yourself & 0 & 14 & 11 & 13 & 2 & 2.08 \\
\hline$s$ & 13 & $\begin{array}{l}\text { You do no feel you have enough } \\
\text { authority to change your teaching }\end{array}$ & 1 & 14 & 11 & 12 & 2 & 2.0 \\
\hline i & 20 & $\begin{array}{l}\text { You do not see the value of research } \\
\text { for practice }\end{array}$ & 0 & 15 & 11 & 13 & 1 & 2.0 \\
\hline & 21 & $\begin{array}{l}\text { There is not a documented need to } \\
\text { change practice }\end{array}$ & 5 & 9 & 14 & 8 & 4 & 1.92 \\
\hline p & 8 & The research has not been replicated & 12 & 1 & 15 & 4 & 8 & 1.87 \\
\hline $\mathrm{p}$ & 11 & $\begin{array}{l}\text { The research has methodological } \\
\text { inadequacies }\end{array}$ & 11 & 6 & 10 & 13 & 0 & 1.63 \\
\hline & 26 & $\begin{array}{l}\text { You are unwilling to change/try new } \\
\text { ideas }\end{array}$ & 1 & 21 & 13 & 4 & 1 & 1.58 \\
\hline
\end{tabular}


Hemsley-Brown J.V. and Oplatka, I. (2005). Bridging the Research-Practice Gap: barriers and facilitators to research use among school Principals from England and Israel, International Journal of Public Sector Management, 18, 5, pp 424-446.

Table III. Results of tests of t-tests

\begin{tabular}{|l|c|c|c|c|}
\hline & Research & Presentation & Setting & Individual \\
\hline t-test value & 0.69 & 0.01 & 0.265 & 0.01 \\
\hline $\begin{array}{l}\text { Mean score } \\
\text { Israel }\end{array}$ & 2.59 & 2.15 & 2.18 & 2.23 \\
\hline $\begin{array}{l}\text { Mean score } \\
\text { England }\end{array}$ & 2.54 & 1.73 & 2.3 & 1.96 \\
\hline $\begin{array}{l}\text { Mean score } \\
\text { (all) }\end{array}$ & 2.56 & 1.89 & 2.23 & 2.06 \\
\hline
\end{tabular}

Table IV. Results of one-way between groups ANOVA tests

\begin{tabular}{|l|c|c|c|c|}
\hline & Research & Presentation & Setting & Individual \\
\hline Mean & 2.57 & 1.9 & 2.23 & 2.07 \\
\hline SD & 0.61 & 0.84 & 0.50 & 0.52 \\
\hline
\end{tabular}

